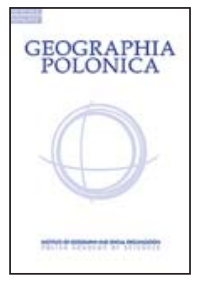

\title{
REBIRTH OF VITICULTURE AND ASSOCIATED CHANGES IN THE RURAL AREAS OF LOWER SILESIA, SW POLAND
}

\section{Edyta Pijet-Migoń (D) • Karolina Królikowska (D)}

WSB University in Wrocław

Fabryczna 29-31, 53-609 Wrocław: Poland

e-mails: edyta.migon@wsb.wroclaw.pl (corresponding author) • karolina.krolikowska@wsb.wroclaw.pl

\begin{abstract}
This paper addresses the problem of how the reborn winemaking in Lower Silesia may contribute to the social, landscape and functional changes of rural areas. Newly established vineyards refer back to the local traditions of grape cultivations which vanished for the variety of reasons. Vineyards are typically small family businesses. The profiles of winemakers show that they are most often educated persons, arriving from cities, who follow their passion and consider winemaking as a supplementary source of income. They are aware of the value of local products, traditions and harmonious landscape and expose these values in both the process of winemaking itself, as well as in developing wine tourism. They support and organize new activities such as music events, recreational events, and guest presentations. Vineyards are new elements of the rural landscape, but they are historically justified and harmoniously integrated with the topography, whereas associated infrastructure usually represents good examples of revitalization of existing buildings, occasionally of architectural value. Due to the family-type business on the vineyards it is rather premature to infer their direct positive influence on local employment and incomes. Nevertheless, due to the growth of wine tourism local suppliers are expected to increasingly benefit from this development trend.
\end{abstract}

\section{Key words}

viticulture - vineyards - wine tourism - rural areas - sustainable development

\section{Introduction}

Winemaking industry is a dynamic business, which shapes the face of many regions in the Old and New World in both physical sense, contributing to the emergence of distinctive landscapes, as well as by imposing changes in the local economy. These changes are direct, arising from the winemaking process itself that creates employment opportunities and generates income, and indirect, related to the growth of wine tourism which includes sightseeing, wine tasting and purchasing. Winery landscapes have been long regarded as a particular example of cultural landscapes (Myga-Piątek \& Rahmonov, 2018), associated with specific architecture, lifestyle, art, and social structures. Many have heritage values 
and are under legal protection, some have even been found to have outstanding universal value and are UNESCO World Heritage. For all these reasons, changes of the rural space in winemaking regions may be profound.

Regarding wine-related landscapes and associated land use change three major processes currently occur: a) vineyard abandonment (Lieskovsky et al., 2013), b) vineyard expansion and/or transformation as an intensive form of agriculture (Lourenço-Gomes, Pinto, \& Rebelo, 2015; Basso, 2019), and c) small-scale vineyard establishment and/ or restoration, usually with respect to historical winery landscapes (Torquati, Giacchè, \& Venanzi, 2015; Greinert, Kostecki, \& Vystavna, 2019). While in some areas vineyards are being abandoned, in other places the area dedicated to viticulture increases. There are also regions where winemaking was present in the past, subsequently disappeared, and is now being reinstated. Southwestern Poland (= Lower Silesia) is one of the regions where the latter process is observed nowadays.

The purpose of this paper is to discuss the impact of newly established vineyards in Lower Silesia, SW Poland, on the rural areas, including social, landscape and functional changes, as present in the very early stage of vineyard growth, as well as possible pathways of development in the near future. Whereas landscape dimension of wine production has often been subject of geographical analysis (e.g., Lugeri et al., 2011; Bruwer \& Joy, 2017; Harea \& Eplenyi, 2017; Foronda Robles, 2018; Myga-Piątek \& Rahmanov, 2018), as has been wine tourism (e.g., Dodd \& Bererland, 2001; Carlsen, 2004; Carlsen \& Charters, 2006; Getz \& Brown, 2006; Hall, Sharples, Cambourne, \& Macionis, 2009), literature on social and functional changes in rural areas related to viticulture restoration is scarce, especially for the early stages of industry development (e.g., Telfer, 2001; Crmichael, 2005; Howley \& van Westering, 2008; Dawson, Holmes, Jacobs, \& Wade, 2011; Schernewski, 2011). Problems of winemaking in Poland was presented in the context of climate change, the most suitable varieties of grapes, changes in consumer behavoiur, whereas the regional coverage of geographical studies was largely limited to wine trails and enotourism (e.g., Kowalczyk, 2003; Olszewski \& Dróźdż, 2013; Rogowski \& Kasianchuk, 2016; Pink, 2017; Kruczek, 2018; Głąbiński \& Koźmiński, 2019). The current state of winemaking industry in SW Poland has not yet been presented and this paper intends to fill this gap. It is focused on vineyard distribution, profiles of winemakers and the role of vineyards in local economy, particularly in tourism industry. However, topics such as agritechnical and biotechnological aspects of viticulture and wine production remain beyond the scope of this paper.

\section{Approach and methods}

Overarching research questions in this study are: (a) how the vineyards contribute to the rural areas of Lower Silesia now, considering both tangible and intangible aspects, and (b) how they may contribute in the future, including sustainability and persistence of winemaking industry. Since winemaking in Lower Silesia is a recent phenomenon and its landscape, social and economic impacts are still minor, available data sources are limited. Therefore, the winemakers themselves were the main source of information used and the evaluation of possible social and functional impacts of vineyards is primarily based on their responses. Information about the social and educational background of vineyard owners and their plans for the future was used as a basis for the predictive part of the paper.

Background materials for this study were largely collected by the authors themselves while performing: (a) field visits to the vineyards to assess their position in the landscape context, (b) applied participant observation during many wine and culinary events, (c) semi-structured in-depth, qualitative interviews with vineyard owners who produce wine for sale, and (d) analysis of vineyards' 
websites and other promotion materials. Interviews included questions concerning economic, environmental, social and cultural aspects of wine making, production, sales and marketing issues, cooperation with different stakeholders, and regional development (Tab. 1). Additional data were obtained from the register of the National Agriculture Support Centre and the website of the Ministry of Agriculture and Rural Development. The total number of analyzed vineyards is eighteen and the prerequisite to include a vineyard for research was the production of wine for sale. This research has been carried out from February 2017 to August 2019.

\section{Viticulture in Poland}

Poland is a country not readily associated with wine production, even among wine enthusiasts. However, this situation may significantly change in the future, since for more than a decade one can observe an increasing interest in wine cultivation and winemaking. Both the number and the total area of vineyards are growing (Pink, 2015; Olewnicki, 2018). Polish wines, particularly white varieties, become appreciated at international wine contests.

Table 1. Content (questions) of the in-depth interviews

\begin{tabular}{|c|}
\hline Supply and demand \\
\hline $\begin{array}{l}\text { - reasons behind opening the vineyard to tourists, benefits and constraints } \\
\text { - tourism-related activities in relation to the entire involvement } \\
\text { - plans to develop tourism activities } \\
\text { - customers, demands and expectations }\end{array}$ \\
\hline Local and regional development, tourist product and brand \\
\hline $\begin{array}{l}\text { - } \text { contribution to regional development and promotion } \\
\text { - participation in culinary tourism initiatives and its effects } \\
\text { - benefits from tourism promotion of the region; personal evaluation of campaigns undertaken by local govern- } \\
\text { - fonts and tourist organizations }\end{array}$ \\
\hline Sustainable tourism - environmental awareness \\
\hline $\begin{array}{l}\text { - environment-friendly solutions in the vineyard related to energy use, resources, waste management; the role } \\
\text { in planning future activities } \\
\text { - visual aspects of wine-making business - harmony of vineyard and winery with local landscape and architec- } \\
\text { ture } \\
\text { - relationships with protected area management (if applicable) } \\
\text { - perception of climate change in the context of winemaking }\end{array}$ \\
\hline Sustainable tourism - social and cultural aspects \\
\hline $\begin{array}{l}\text { - cooperation with local communities - joint activities, conflicts, visitations; influence of vineyard on the local } \\
\text { - community } \\
\text { - visitors' opinions - how collected and considered? } \\
\text { - restrictions in access; opportunities for handicapped people } \\
\text { - inspirations from local culture and traditions, particularly traditions of winemaking (if applicable) }\end{array}$ \\
\hline Sustainable tourism - economical aspects \\
\hline $\begin{array}{l}\text { - employment opportunities for local people (permanent or seasonal, if any); training activities } \\
\text { - support of local producers and service providers } \\
\text { - economic impact of vineyard on local communities } \\
\text { - non-materials benefits of local communities from the existence of vineyard (e.g., use of vineyard infrastructure } \\
\text { - gathering halls, access roads) }\end{array}$ \\
\hline
\end{tabular}

Source: own elaboration 
The contemporary growth of Polish winemaking industry has been caused by several factors, such as the change in the model of alcohol consumption towards lower alcohol volumes and increasing popularity of wine (Bosak, 2013), the growth of consumers' awareness about health-promoting properties of wine (Błaszczyk \& Krzywonos, 2015), as well as ongoing warming of climate (Lisek, 2008; Żmudzka, 2009; Kundzewicz, 2011; Kunicka-Styczyńska Czyżowska, Ratajkowska, Witkowska, \& Dziugan, 2016) and the emergence of grape varieties more tolerant to low temperatures (Pink, 2015; Kunicka-Styczyńska et al., 2016). Moreover, legal regulations regarding wine production have recently changed and various EU-funded projects aimed at activation of rural areas were implemented (Piątyszek-Pych, 2012; MazurkiewiczPizło \& Pizło, 2018). Considerable positive impact on the development of winemaking in Poland was also due to activities of various wine-related associations and organizations (Mazurkiewicz-Pizło, 2013, 2014).

Organization of wine market in Poland is regulated by the Act from 12 May 2011 concerning production, bottling and trading of wine products (Journal of Laws 2018, item 1159). In compliance with this act, production of wine from grapes collected from plantations located in Poland and intended for sale requires inscription onto the list managed by the Director General of the National Support Centre for Agriculture ${ }^{1}$ (KOWR). According to the KOWR database the number of vineyards involved in wine for sale production has grown nine-fold in just one decade. In 2009, there were only 26 registered winemakers in Poland, cultivating a little over 36 ha of grapevine plantations, whereas in May 2019 as many as 230 vineyards occupying 395 hectares in total existed. Annual production of wine for sale reached $12,716 \mathrm{hl}$. Production of white wine dominates, accounting for $61 \%$ of all wine bottled in 2018 (www.kowr.gov.pl). In reality, the area

\footnotetext{
1 Krajowy Ośrodek Wsparcia Rolnictwa (KOWR) in Polish
}

used for grapevine cultivation is larger and the number of vineyards is higher as becomes evident from various websites run by the winemakers themselves and organizations involved in winemaking (e.g., winogrodnicy. pl). However, many of these vineyards are yet to yield harvest since they have been established very recently, or wine is produced for personal consumption only and has not been introduced to the market.

According to the European Union classification of climate for viticulture, Poland belongs to the coldest wine-growing region (A), which also includes Germany (except for Baden), the Czech Republic (except for Moravia), Denmark, Belgium and Great Britain (Kunicka-Styczyńska et al., 2016). The average temperatures in spring and summer in Poland are relatively high, but day-to-day fluctuations and potential problems of frost and hailstorm occurrences are significant climate-related constraints (Lisek, 2008).

Poland is dominated by small vineyards, occupying a mere few hectares. They cluster in several regions, reflecting the most favourable climatic conditions for grapevine cultivation. Following the proposal of Polish Convent of Winemakers, the division of Poland into wine regions was adopted (Poczta \& Zagrodzka, 2016) (Fig.1):

- Zielona Góra region (I)

- Lower Silesia (II)

- Małopolska region (including Śląskie and Świętokrzyskie voivodships) (III)

- Fore-Carpathian region (IV)

- Małopolska Vistula Gap (and Lubelskie voivodship) (V)

- Central and northern Poland (VI)

Among them, regions no. I to III have the largest areas used for vine cultivation (Olewnicki 2018).

The above division alludes to areas historically connected with grapevine cultivation, whose onset dates back to medieval times. Archeological excavations in Kraków, at the foot of Wawel hill, confirmed the existence of vineyards as early as the $9^{\text {th }}$ century (Kosmaczewska, 2008; Pink \& Kokoszka, 2018). The oldest vineyards were established 
by Cistercian and Benedictine abbeys and wine was produced, among others, in Tyniec (close to Kraków) and along the foothills of the Carpathians. Large centres of winemaking were the towns of Przemyśl and Sandomierz, whereas further evidence of the presence of vineyards comes from the vicinities of towns such as Zielona Góra, Poznań, Toruń, Płock and Lublin. The peak of wine production occurred in the 14th-15th century (Rzeszotarska-Pałka, 2012; Myśliwiec, 2013; Wawro, 2015), followed by decline in the 16th-17th centuries, when consumption of beer and spirits began to grow. Price differences dictated the popularity of imported wine, particularly from Hungary (Matkowski \& Miętkiewicz-Brynda, 2015). These social and economic trends coincided with climate cooling (Little Ice Age period) and phylloxera outbreak, resulting in considerable decrease of winemaking industry in Poland (Pink, 2015). Modest revival occurred in the 19th century, particularly in the vicinity of Zielona Góra, Poznań and in Lower Silesia (Bardel \& Gogoliński, 2018), which at that time were part of Prussia. In the 1920s and 1930s the Grempler winery in Zielona Góra (then Grünberg in Germany), specializing in sparkling wine, was the largest factory of this kind in Germany and was known all over Europe (Greinert et al., 2019).

After the World War II grapevine cultivation for wine production was practically abandoned in the entire country. The 1960s were typified by the closure of research and educational facilities focused on winemaking and enology such as Grapevine Institute in Skierniewice and the high school in Zielona Góra, whose education profile was directed towards fruit growing and winemaking. In the following years, grapevine was cultivated only in private gardens and used for personal consumption. The renewal of interest in winemaking occurred only after political and economic breakthrough in Poland, in the 1990s, enhanced in the early 21st century (Dobrowolska-Iwanek et al., 2014; Olewnicki, 2018).

Alongside the revival of winemaking in Poland and growing interest in wine among consumers, wine tourism began to develop.
Visits to vineyards, including wine tasting, have become popular and accommodation and gastronomic facilities were established at some vineyards. The tourist potential of wine regions was used to create thematic wine trails. The most known and efficiently promoted ones from outside Lower Silesia are the Lubusz Route of Wine and Fore-Carpathian Vineyard Route and Małopolska Wine Trail (Piątyszek-Pych, 2012; Woźniczko, Jędrysiak, \& Orłowski, 2015; Rogowski \& Kasianchuk, 2016).

\section{Winemaking traditions in Lower Silesia}

In common with other regions of Poland, winemaking traditions in Lower Silesia go back to the medieval era. Vineyards were established by monks, particularly by the Cistercian order, next to abbeys and then larger towns (Pink, 2015). Historical evidence confirms the establishment of vineyards in the proximity of Wrocław, Świdnica, Trzebnica, Milicz, Środa Śląska and Lubiąż(Fig. 1). Winemaking legacy is hinted at if one considers place names such as Winna Góra (Wine Hill), Winne Wzgórze (Wine Hillock) or simply Winnica (Vineyard). Grapevine features in the coat of arms of several settlements (e.g., Środa Śląska, Wińsko, Mściwojów). Wine cultivation was favoured by suitable natural conditions, including mild climate, moderately hilly terrain with good sunlight exposure, and good soils, among them those developed from loess.

In Lower Silesia, the town of Środa Śląka is most readily associated with wine. Throughout the centuries winemaking and wine trading were of crucial economic significance for the local population. These traditions are nowadays recalled during an annual Wine Festival, organized since 2005.

Historical sources show that climatic changes at the turn of the 16th century had considerable impact on winemaking and the area subject to grapevine cultivation diminished (Myśliwiec, 2013). During Prussian times (since 1742) attempts were made to re-establish some of the old vineyards, 
but these new enterprises could not successfully compete with much cheaper wines produced in other regions of Prussia (later Germany), and gradually lost significance. Prior to the World War II the total area used for grapevine cultivation in Lower Silesia was c. 200 ha (Ministry of Agriculture and Rural Development, Traditional Products List 2019).
During the war winemaking was completely suspended and the old traditions were not followed afterwards. This was largely due to the lack of adequate skills and experience among the new settlers who arrived at Lower Silesia after the war. Grapevine cultivation was a hobby for a small number of people and total production was negligible.

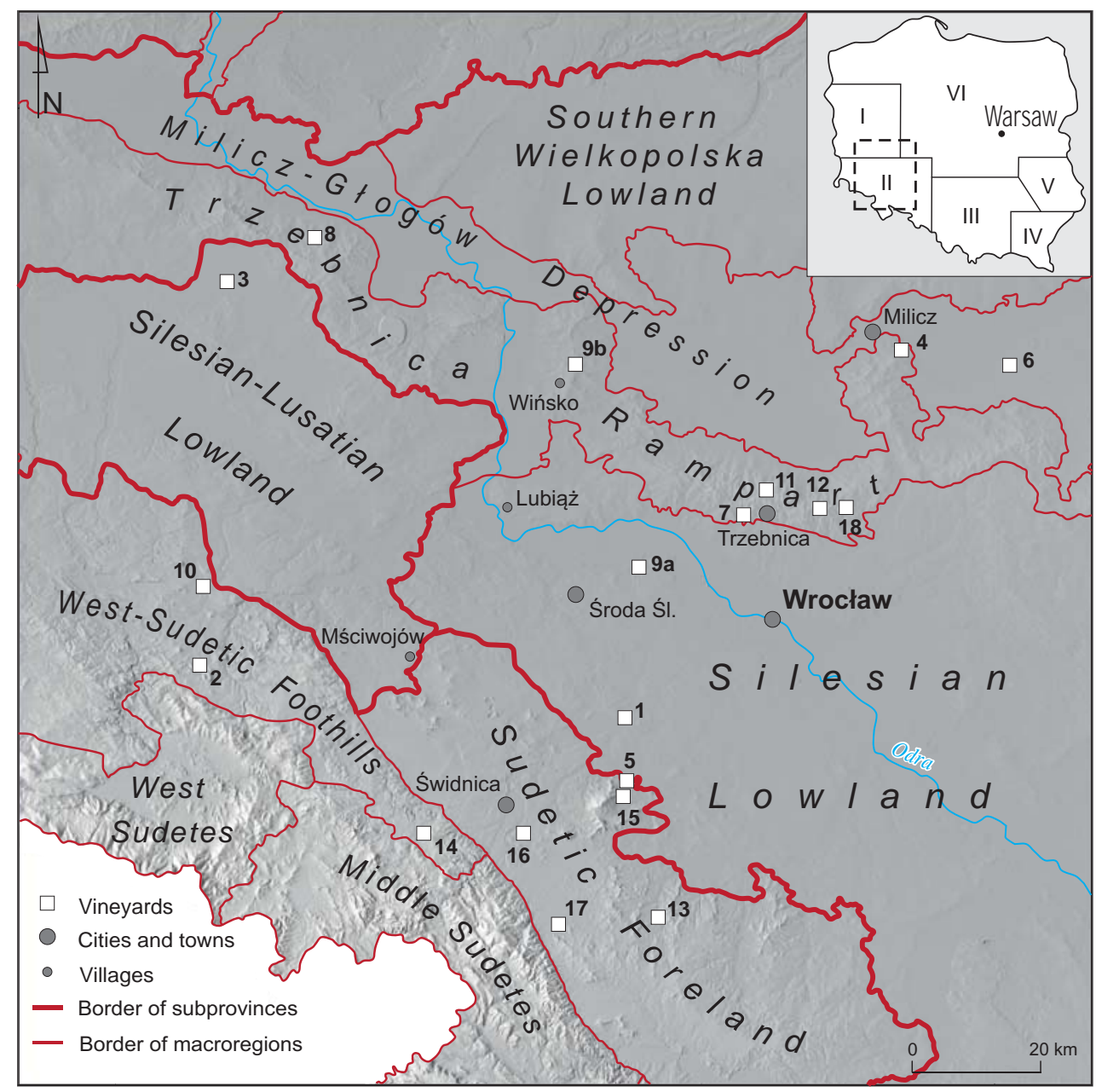

Figure 1. Location of Lower Silesian vineyards in relation to physical geography regionalization (boundaries of geographical macroregions after Solon et al., 2018). Inset shows the general division of Poland into wine regions. I - Zielona Góra region, II - Lower Silesia, III - Małopolska region (including Śląskie and Świętokrzyskie voivodships), IV - Fore-Carpathian region, V - Małopolska Vistula Gap (and Lubelskie voivodship), VI - Central and northern Poland. Names of analysed vineyards (as in Tab. 2): 1 - Adoria, 2 - Agat, 3 - Alvarium, 4 - Anna, 5 - Celtica, 6 - De Sas, 7 - Jadwiga, 8 - Jakubów, 9 a, b- Jaworek, 10 - Kindler, 11 - L’Opera, 12 - Moderna, 13, Niemczańska, 14 - Otok, 15 - Spod Ślęży, 16 - Świdnicka, 17 - Bielawska, 18 - Wzgórza Trzebnickie. 
The renewed interest in winemaking occurred the beginning of the 21st century. One of the earliest vineyards established in the region is Jaworek, operating since 2001 in the village of Miękinia, between Wrocław and Środa Śląska (Fig. 1). After several years of trial and error, as emphasized by the owners themselves, the first wine intended for sale was produced in 2008 and made its way to various exclusive restaurants in the country, enjoying favourable reviews from connoisseurs. It also attracted an interest from the media, which contributed to the subsequent recognition of Jaworek brand name.

In 2019, grapevine in Lower Silesia was cultivated in more than 30 vineyards, whose total surface area is estimated for 70-90 hectares. Unfortunately, no reliable official data are available and different sources provide conflicting information. This is because not all new vineyards are included in the KOWR register. Setting of new vineyards is an ongoing process, as is extension of the existing ones, but harvests will be possible in a few years only.

\section{Characteristics of vineyards}

The total of 18 vineyards in the region (Fig. 1) collectively occupies 62.5 hectares. Apart from the oldest Jaworek vineyard, which currently spreads over 23 ha at two different localities (near Miękinia and Wińsko), all the remaining ones are very small, with an area of a few hectares, whereas four of them are less than 1 hectare (Tab. 2). Most vineyards are located in hilly lands of the Trzebnica Rampart and the Sudetic Foreland, usually best suited for grapevine cultivation, at the

Table 2. General characteristic of analysed vineyards

\begin{tabular}{|c|c|c|c|c|c|}
\hline No & $\begin{array}{c}\text { Name } \\
\text { of the vineyard }\end{array}$ & $\begin{array}{l}\text { Location } \\
\text { - name of the village/ } \\
\text { small town }\end{array}$ & $\begin{array}{c}\text { Location } \\
\text { - macroregion }\end{array}$ & $\begin{array}{c}\text { Year } \\
\text { of foundation }\end{array}$ & $\begin{array}{l}\text { Surface } \\
\text { in ha }\end{array}$ \\
\hline 1 & Adoria & Zachowice & Silesian Lowland & 2005 & 3.50 \\
\hline 2 & Agat & Sokołowiec & West-Sudetic Foothills & 2007 & 1.50 \\
\hline 3 & Alvarium & Ostaszów & $\begin{array}{l}\text { Silesian-Lusatian } \\
\text { Lowland }\end{array}$ & 2012 & 0.35 \\
\hline 4 & Anna & Krośnice & $\begin{array}{l}\text { Milicz-Głogów } \\
\text { Depression }\end{array}$ & 2014 & 0.80 \\
\hline 5 & Celtica & Sobótka & Sudetic Foreland & 2014 & 1.50 \\
\hline 6 & De Sas & Czeszyce & $\begin{array}{l}\text { Milicz-Głogów } \\
\text { Depression }\end{array}$ & 2006 & 3.00 \\
\hline 7 & Jadwiga & Mienice & Trzebnica Rampart & 2015 & 1.00 \\
\hline 8 & Jakubów & Jakubów & Trzebnica Rampart & 2002 & 5.00 \\
\hline 9 & Jaworek & $\begin{array}{l}\text { Miękinia }(9 a) \\
\text { Wińsko }(9 b)\end{array}$ & $\begin{array}{l}\text { Silesian Lowland } \\
\text { Trzebnica Rampart }\end{array}$ & 2001 & 23.00 \\
\hline 10 & Kindler & Uniejowice & West-Sudetic Foothills & 2012 & 2.00 \\
\hline 11 & L'Opera & Trzebnica & Trzebnica Rampart & 2014 & 2.00 \\
\hline 12 & Moderna & Krakowiany & Trzebnica Rampart & 2016 & 1.60 \\
\hline 13 & Niemczańska & Niemcza & Sudetic Foreland & 2017 & 3.10 \\
\hline 14 & Otok & Pogorzała & West-Sudetic Foothills & 2011 & 6.00 \\
\hline 15 & Spod Ślęży & $\begin{array}{l}\text { Sobótka/Strzego- } \\
\text { miany }\end{array}$ & Sudetic Foreland & 2015 & 0.80 \\
\hline 16 & Świdnicka & Makowice & Sudetic Foreland & 2004 & 3.70 \\
\hline 17 & Bielawska & Bielawa & Sudetic Foreland & 2015 & 0.25 \\
\hline 18 & Wzgórza Trzebnickie & Węgrów & Trzebnica Rampart & 2008 & 3.50 \\
\hline
\end{tabular}


altitude of 200-300 m a.s.l., relatively close to the city of Wrocław (up to 50-60 km), the biggest one in the region. Lowlands, by contrast, are clearly not attractive places to establish vineyards. Four vineyards have been founded in the surroundings of the town of Trzebnica, known for fertile loess-derived soils.

All vineyards are of very recent date. Only seven out of eighteen have operated for more than 10 years, whereas five are less than 5 years old. Different grape varieties are cultivated. Often, despite small size, many varieties are tried and according to the interviews, vineyards are still at an early, experimental stage. The commonly grown white varieties are Riesling, Solaris, Seyval Blanc, Hibernal, Johanniter and Gewürztraminer, whereas Regent, Rondo, Cabernet Cortis, Pinot Noir and Dornfelder dominate among red varieties.

The profile of winemakers shows that they are most often educated persons, who arrive from cities, are motivated by passion and consider winemaking as a supplementary source of income. Out of the 18 vineyards studied, in 5 cases only the owner (owners) comes from the local community, in the remaining 13 cases they have arrived from a different place (Tab. 3). In two cases expats are involved in winemaking (from California, USA and Italy). Only in 3 cases the vineyard is the main source of income and only in two cases the winemaker has formal education related to agriculture. In five cases grapevine production is accompanied by other activities, e.g., currant wine production, beekeeping, and fruit-growing and cider production.
Both the interviews and observations reveal that winemakers are aware of cultural and natural values of the region and take care of the cultural heritage of the village. Evidence includes utilization/renovation of valuable historic buildings, references to the local landscape and tradition in wine label designs as well as on vineyard websites and Facebook profiles, inclusion of their products on local product lists. Moreover, they introduce new forms of activity, e.g., initiate development of tourism, sport and recreation or create the cultural offer. This is in line with the general nature of rural activation, often initiated by newcomers from large cities, who settle in the countryside (Sadura, Murawska, \& Włodarczyk, 2017).

The intensity of cooperation of winemakers with the local community varies. Some winemakers reported that initially, while setting up a vineyard, they encountered the problem of thefts of seedlings. Possibly as a consequence, most of vineyards are fenced, which is not a normal landscape element in countries with long winemaking traditions. On the other hand, winemakers cooperate with local suppliers and use local products to prepare tastings and menus. Local Action Groups (LAG) are a natural partner for winemakers. These are territorial partnerships created in rural areas, bringing together representatives of local organizations (from the public, private and non-governmental sectors) and residents of a given area, designated by the boundaries of member communes. For example, in the LAG Kaczawskie Partnership, both Agat and Kindler vineyards are involved

Table 3. Social profile of the vineyard owners

\begin{tabular}{|l|l|c|}
\hline \multicolumn{2}{|c|}{ Profile of vineyard owners } \\
\hline Ancestry & from local society & 5 \\
& not from local society, but long settled in the area & 4 \\
& no local connection, still living in different place & 9 \\
\hline & Yes & No \\
\hline Education background connected with agriculture & 2 & 16 \\
Vineyard and winemaking as main source of income & 3 & 15 \\
\hline
\end{tabular}

Source: based on interviews 
in joint activities (Pijet-Migoń \& Migoń, 2019). In addition, some winemakers cooperate with local restaurants and hotels, e.g., organize wine tastings and actively participate in local events. All these activities allow one to suppose that these people have the potential to become local leaders, but at the current stage of research and wine industry development in the region there is no sufficient data to assess how winemakers are perceived by local communities.

Vineyards are typically small family businesses. Due to family-type business at vineyards it is rather premature to infer their direct positive influence on local employment and incomes. Local people are employed only seasonally, during the grape harvest. Nevertheless, due to the growth of wine tourism and an increasing number of vineyards local suppliers are expected to increasingly benefit from this development trend. On the other hand, the lack of winemaking family traditions means that there is no guarantee that this activity will continue for long. Current winemakers are invariably the first generation dealing with viticulture, which involved substantial investment of own funds and a huge learning effort. In some cases, the next generation is involved in grape cultivation and winemaking, however it is not certain whether it will turn into a lasting tradition or not.

\section{Vineyards and local landscape}

Vineyards established in Lower Silesia continue the tradition of viticulture, which experienced a gap lasting at least more than half a century. They constitute a new element in the landscape, but historically justified and harmoniously integrated with the landscape (Fig. 2). The accompanying infrastructure is usually a successful example of revitalization of existing buildings of historical value (Fig. 3). The plantation itself is usually a small vineyard patch in a mosaic landscape of different land use types (forests, meadows, orchards, villages), with limited visible identity and, except a few cases, poorly recognized from the distance (Fig. 2). Therefore, given also that their size usually does not exceed $3 \mathrm{ha}$, it is not yet legitimate to call it a winescape. Undoubtedly, however, the landscape surrounding the vineyards is considered by most winemakers as an additional asset that can encourage visitations (Fig. 2). This is indicated by the analysis of the notes on the Wine and Beer Route website, where many winemakers refer to the local landscape in the section "Why visit our vineyard?", as presented in the examples below (authors' own translations).

"The vineyard is located near the Stawy Milickie Nature Reserve and the Barycz Valley Landscape Park. The area is perfect for cyclists. There is a network of bicycle routes, paved forest roads and local roads that stretch along the charming Krośnickie Hills" (Anna Vineyard)

"Bielawa lies at the foot of the oldest mountains in Europe - the Sowie Mountains, $50 \mathrm{~km}$ from Wroclaw. In Bielawa there is probably the most beautiful water reservoir in Poland with an area of nearly 24 haLake Bielawskie" (Bielawska Vineyard). "The name of the vineyard comes from the name of the charming, ancient village located on the Dalków Hills. From the 12th century to the present day, Jakubów has attracted guests from all over Europe. A 14th-century church made of erratic stones, together with a pilgrimage sanctuary the St. Jacob Spring, located in the nearby nature reserve "Buczyna Jakubowska" impress the visitors no less than the ruins of the neo-gothic palace and the park around them" (Jakubów Vineyard) ${ }^{2}$.

Some winemakers revitalized old buildings in line with local architectural tradition (Fig. 3). The owners of the Jaworek vineyard have restored the 18th century buildings, where wine production currently takes place. The owners of the Celtica vineyard purchased the Old Gasworks complex in Sobót$\mathrm{ka}$ in 2012, initially without an idea how to use it and sufficient money for renovation.

\footnotetext{
2 Dolnośląski Szlak Piwa i Wina (Lower Silesia Trail of Beer and Wine): www.dspiw.pl [access 30 August 2019]
} 


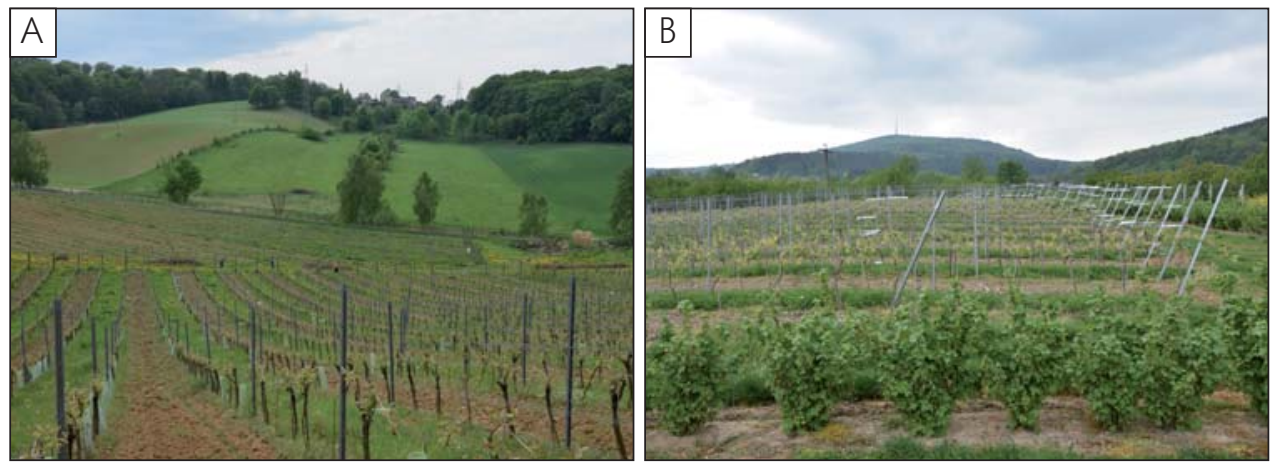

Figure 2. Vineyard landscapes: A - Vineyard Jakubów in the rolling scenery of the Dalków Hills, B - Vineyard Celtica, with Mt Ślęża in the background
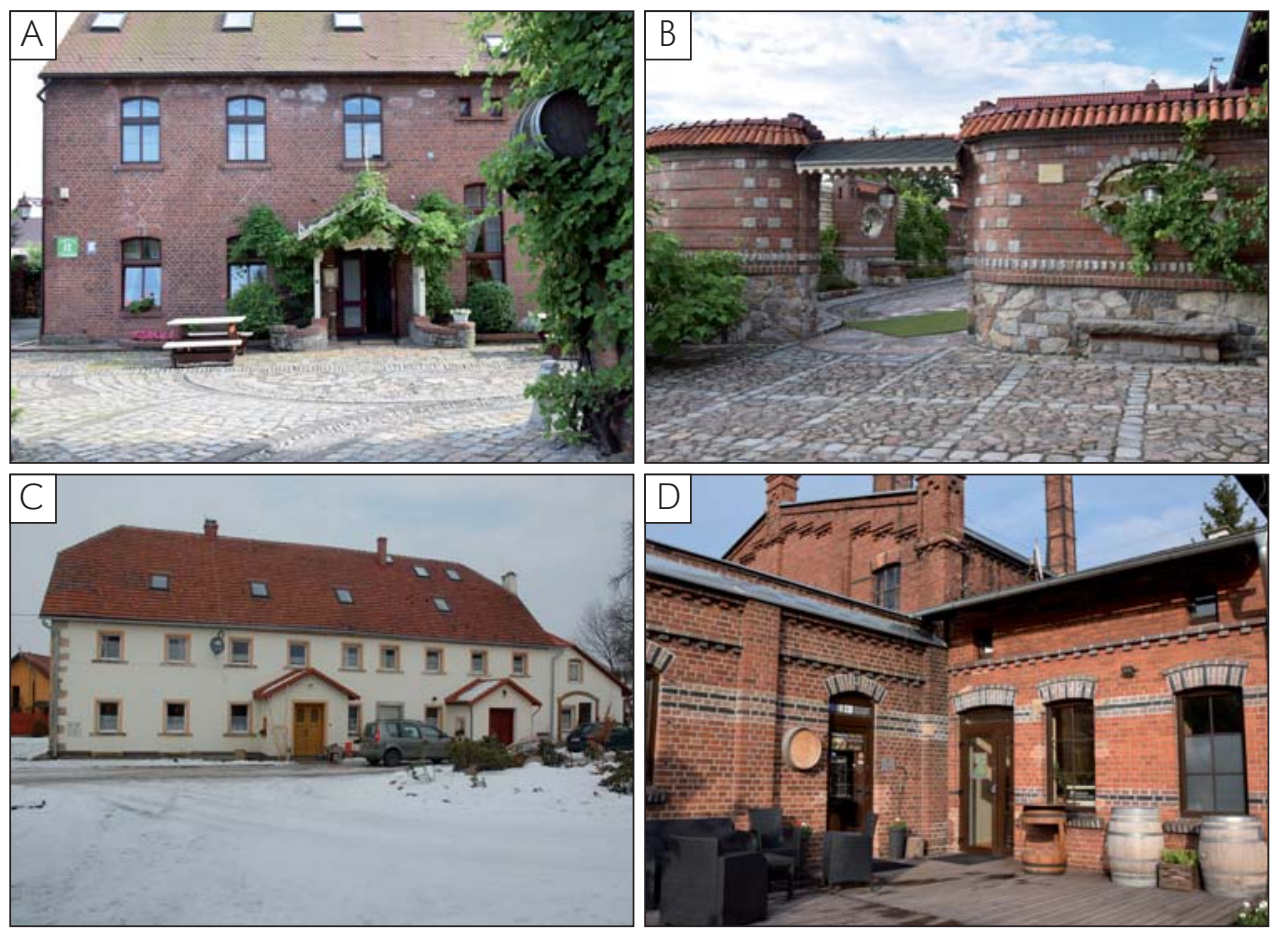

Figure 3. Examples of revitalized traditional architecture: A, B - Jaworek Winery - old farm, C - Agat Winery - old farmhouse, D - Celtica Winery - old gaswork.

As they began to deal with winemaking for their own use at the same time, a decision was made to adapt the building to serve wine production and related activities. Although the building is now used as a winery and a small hotel, all important elements of the gasworks technological process were kept.
All elements of the interior, such as decorative window hungers and lamps made of wine barrels and bottles, were hand-made by local artists, builders, carpenters, and the owners themselves. Thanks to local contractors, architects and partly EU subsidies, they were able to combine the history of gas industry 
with modern winemaking. The winery itself was established in a room where coal was stored during the Gasworks' heyday. During renovation works, coal was found in different parts of the building and the original floor with the coal can be seen today under an armored glass. The room smells of light coke, sulfur and tar, which were by-products of dry coal distillation.

\section{Development of tourist function}

Parallel to an increasing interest in buying local products, including wine, consumers seek more information about these products and localities where they are made. Simultaneously, vineyard owners declare that they look for sources of additional income and explore various promotional channels. Consequently, in most vineyards it is now possible to visit both the plantation itself, as well as the winery (Tab. 4). Sightseeing usually includes oral presentation about grape cultivation followed by winemaking, tasting and opportunity to purchase the products. In five vineyards it is possible to arrange more specialized sommelier courses and workshops. Since the small size of vineyards and the related low number of employees are constraining factors, these options typically require special arrangements and advance bookings. They are offered to both formal and informal groups.

Interviews with vineyard owners reveal that personal visits to vineyards significantly influence sales. Similarly to trends in other areas (Alant \& Bruwer, 2004; Bosak, 2013), between 50 and $75 \%$ of visitors are estimated to buy at least one bottle at the end of the visit. In order to enhance attractiveness and comfort, the owners erect the so-called small tourist infrastructure, which includes rest areas and shelters, allowing for visitations also during adverse weather conditions (Celtica, Jakubów), wine tasting rooms, big enough to make presentations and workshops possible (Adoria, Agat, Celtica, Jaworek), walking trails through the vineyard and viewing

Table 4. Tourist function of vineyards

\begin{tabular}{|c|c|c|c|}
\hline Vineyard & $\begin{array}{c}\text { Organized visits } \\
\text { to vineyards }\end{array}$ & $\begin{array}{c}\text { Accommodation } \\
\text { options }\end{array}$ & $\begin{array}{l}\text { Other tourist } \\
\text { activities }\end{array}$ \\
\hline Adoria & + & - & different events \\
\hline Agat & + & own $B \& B$ & $\begin{array}{l}\text { thematic meetings, geo- } \\
\text { logical exhibition }\end{array}$ \\
\hline Alvarium & + & - & - \\
\hline Anna & + & guest rooms & - \\
\hline Celtica & + & own B\&B & meetings with travellers \\
\hline De Sas & + & guest house & jazz concerts \\
\hline Jadwiga & + & - & - \\
\hline Jakubów & + & guest rooms & local sightseeing trips \\
\hline Jaworek & + & hotel & restaurant \\
\hline Kindler & + & - & - \\
\hline L’Opera & - & - & - \\
\hline Moderna & + & - & picnics with food tasting \\
\hline Niemczańska & + & hotel & restaurant \\
\hline Otok & - & - & - \\
\hline Spod Ślęży & + & - & - \\
\hline Świdnicka & + & in plans & picnics with local products \\
\hline Bielawska & + & - & - \\
\hline Wzgórza Trzebnickie & + & - & - \\
\hline
\end{tabular}


spots, with panoramic views of both the vineyard and the surroundings (Adoria, Świdnicka vineyard)

Some wineries also offer accommodation options, either at the vineyard itself or in cooperating tourist enterprises nearby (Królikowska \& Pijet-Migoń, 2018). Accommodation standards vary, from simple guest rooms to comfortable pensions and hotels. Two hotels (at Jaworek and Niemczańska vineyards) have restaurants serving local food and wine, whereas wine tasting with the relevant commentary is also possible.

Vineyards involved in enotourism contribute to the promotion of villages in which they are located and to the increase of their attractiveness for tourists. Some of these villages, such as Zachowice, Miękinia or Sokołowiec, were not considered tourist destinations at all, or visited sporadically, but now their visibility is enhances and winemakers report a growing number of tourists.

Development of enotourism may provide additional income for vineyard owners, create new permanent jobs and help to manage human resources in periods of less work at the vineyard or winery itself (Bruwer, 2003; Getz \& Brown, 2006). However, at the same time it may be difficult for the vineyard owners to be involved in both winemaking and tourism business, especially if the enterprise is small and the number of staff is limited (Mazurkiewicz-Pizło, 2012). This limitation particularly applies in the summer period and during weekends, when more frequent visitations interfere with the necessary work in the vineyard. Nevertheless, winemakers are aware of the importance of enotourism in building brand names and developing relations with consumers, as it may result in repetitive purchases. Therefore, as stressed by the winemakers in the interviews, the majority of them intends to develop tourist function of their vineyards. Furthermore, for the last few years one can observe beginnings of cooperation between winemakers focused on joint promotion and building tourism network products. Owing to the efforts of the "Lower Silesian Vineyards" ("Winnice
Dolnośląskie") association of regional winemakers, established in 2014, a thematic "Lower Silesian Route of Beer and Wine" was created in December 2018, in collaboration with the owners of small craft breweries and with the support of the Marshall Office of Dolnoślaskie Voivodship. Mutual promotion of local producers of wine and beer is among the key aims of this initiative.

Numerous culinary events and festivals, flourishing in the last years and readily attended by winemakers, provide additional opportunities for promotion of wine culture and direct sale. The most popular and heavily frequented are "Europe on the fork", "Wroctaw Feast - Wine and Beer Festival", "Wrocław Summer. Festival of Craft Products", "Celebrating Cheese and Wine", and "Winemakers and Friends" 3 as the most recent initiative of winemakers' association. Thus, involvement in enotourism since the very beginning of winemaking activities is a distinguishing feature of Lower Silesian vineyards. In traditional wine regions enotourism tends to develop usually after a vineyard achieves good reputation, being characteristic for the mature phase in product life cycle (Dodd \& Beverland, 2001)

\section{Development of educational and cultural functions}

Thanks to the development of enotourism new wineries start to play an educational role. Enotourism, as a form of culinary tourism, is part of cultural tourism typified by evident educational and cognitive component (Pikkemaat, Peters, Boksberger, \& Secco, 2009; Kowalczyk, 2010). Guides to the wineries (e.g., Jakubów, Celtica, De Sas) provide information not only about the wine industry itself, but set it in a wider regional and historical context. Some wineries (e.g., Jaworek) participate in a project "Your tourist guide behind the counter" coordinated by the Lower

\footnotetext{
3 Polish names of the events: Europa na widelcu, Wrocławska feta - festiwal wina I piwa, Wrocławskie lato, festiwal produktów rzemieślniczych, Święto serów i wina, Winiarze i przyjaciele.
} 
Silesian Tourist Organization. Within the project, visiting tourists receive brochures, leaflets and other publications but also some advice about sites of interest in the vicinity of the winery.

Some vineyards provide information about the region in which they are located and its highlights through their websites and social media communication channels. For example, De Sas does so about the Barycz Valley Landscape Park, whereas Agat and Kindler wineries, both established in the Kaczawa Foothills region, promoted under the brand name "Land of Extinct Volcanoes" in recognition of the volcanic geological past (Pijet-Migoń \& Migoń, 2019), highlight geoheritage and volcanic sites to be visited. Actually, the very name "Agat", of both the winery itself and wine produced therein, refers to a mineral which is an informal symbol of the region. While visiting the winery one can also see an exhibition of rocks and minerals, and geological fair is organized on a regular basis.

Not uncommonly, owners of new vineyards share their passions and interest with visitors through various events organized at wineries. In doing so, they are building unique identities of individual vineyards and strengthen their brand names. For example, following the catch phrase "Wine likes jazz, jazz likes wine", De Sas Winery offers music experience, especially jazz concerts. Not only have they attracted local people, but also visitors of more distant origin. This is particularly true regarding 11 November festival on Saint
Martin's Day, considered a saint patron of winemakers. Part of the vineyard is the "Vineyard of Masters" - a designated place where grapevines were planted by musicians playing at the spot (Fig. 4A). Another cultural landmark are beautifully decorated kvevri amphorae, created by a Georgian artist Leri Papidze (Fig. 4B).

At other vineyards (e.g., Agat, Jaworek) the owners organize gatherings focused around tasting products from other wine regions and countries. For instance, at Agat winery one could attend such events dedicated to Moravian, Argentinian and Spanish wine, whereas at Celtica open meetings with travellers and authors of travel literature are conducted.

\section{Future of Lower Silesian vineyards - how experience from other areas may inform predictions}

The newly established vineyards contribute to the development of non-agricultural functions of rural areas, particularly the tourist function. It is commonly assumed (Carlsen \& Charters, 2006; Hall et al., 2009) that tourism in regions with centuries-long traditions of winemaking has its roots in Grand Tour phenomenon, when visits in vineyards of southern Europe were an essential part of the experience of travelling aristocracy. However, only in the mid-19th century winescapes and wine culture began to attract larger groups of tourists. The first wine trail ever was created in Germany in the 1920s (Hall et al.,
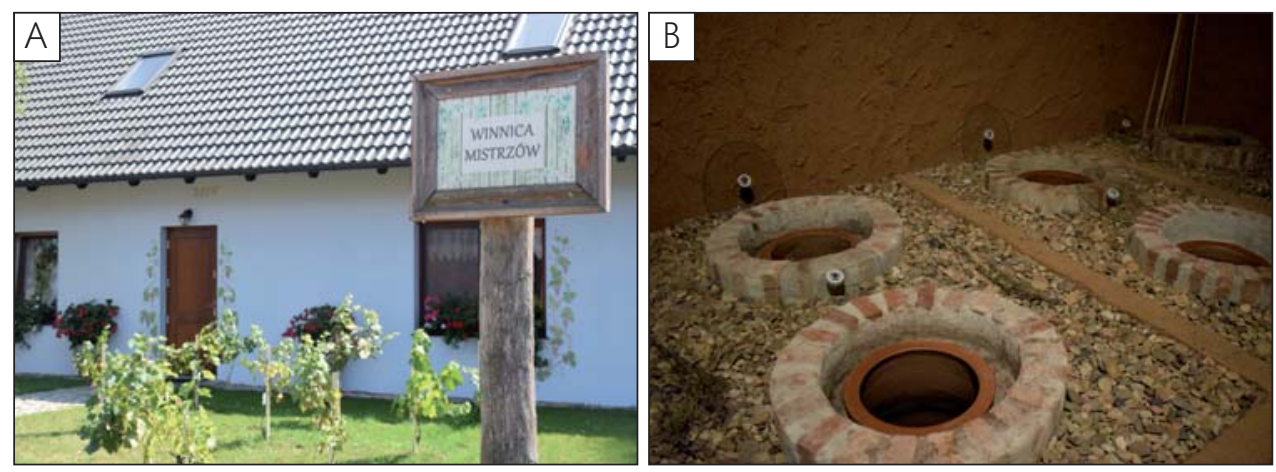

Figure 4. Vineyard De Sas: A - Vineyard of Masters, B - Kvevris 
2009), followed by similar initiatives in France, Spain and Italy (Kowalczyk, 2003; Carlsen \& Charters, 2006). For many years, though, wine-related tourism was practiced by the contemporaneous elites. The wider development started as late as the 1990s (Carlsen \& Charters, 2006). At that time, expansion of wine tourism was also seen outside Europe, from the famous Napa Valley in California, USA, to Australia, New Zealand and South Africa (Bruwer, 2003). Likewise, wine routes were established in Central European countries such as Austria, Hungary, Czechia and Slovakia, in order to provide additional attraction and increase tourist visitations. Economic benefits arising from enoutourism, for both the vineyards themselves and the regions, were quickly realized (Alant \& Bruwer, 2004; Carlsen \& Charters, 2006; Getz \& Brown, 2006; Hall et al., 2009). Evidently, in Lower Silesia vineyard owners have realized the significance of wine tourism in promotion and brand building of their products too since the beginnings of their involvement in winemaking.

Experience from well-established wine regions is usually carefully studied by the owners of new wine businesses in localities, where wine culture was non-existent. Grapevine cultivation in new regions was possible due to climate change and the general warming trend, as well as thanks to the development of new grapevine variants, more resistant against low temperatures. These regions include, first of all, southern Canada (Carmichael, 2005; Dawson et al., 2011), England and Wales (Howley \& van Westering, 2008; Nesbitt, Kemp, Steele, Lovett \& Dorling, 2016), Denmark and southernmost parts of Sweden (Schernewski, 2011) and Finland (Karvonen, 2017). Vineyards in these countries, similarly to Lower Silesia, occupy small areas and may be considered as boutique wineries. Nevertheless, many are involved in tourism business. Ontario province in Canada is often presented as a model example of cooperation between winemakers, tourism industry and local governments towards building of economy clusters and alliances aimed at joint promotion and regional development (Carlsen \& Charters, 2006; Hall et al., 2009; Dawson et al., 2011). Signs of similar cooperation can already be seen in Lower Silesia.

The subject of economic significance of enotourism and benefits arising from cooperation has been a popular field of studies (e.g., Dodd \& Beverland, 2001; Howley \& van Westering, 2008; Dawson et al., 2011; Bosak, 2013; Mazurkiewicz-Pizło, 2014). These studies show how enotourism contributes to sale increases of locally produced wine and how visitors develop emotional commitment to the local brands, both at particular wineries and from the regions as a whole. There are also numerous studies focused on the social profile of enotourists and motivations to get involved in wine tourism (Charters \& Ali-Knight, 2002; Garibaldi, Stone, Wolf, \& Pozzi, 2017; López-Guzmán, Vieira-Rodríguez, \& Rodríguez-García, 2014). However, studies of this kind are not yet available for Lower Silesia, so that the scope for comparative analysis is limited.

According to research carried out in different regions, motivations behind visitations are somehow different in Europe from those identified in the New World (Charters \& Ali-Knight, 2002; Carlsen, 2004; Alonso \& O'Neill, 2009; Shor \& Mansfeld, 2009). In European countries the learning component appears important, including the willingness to discover new places and to acquire information about wine production and grapevine varieties. By contrast, recreation function is an important one outside Europe, whereas an opportunity to relax in a visually appealing scenery and the possibility of direct purchase from the producers are also emphasized. This type of research, focused on motivations, was carried out by Charzyński and Podgórski (2017) in Poland, but on a very small scale.

The enotourism offer of Lower Silesian vineyards, although still rather modest, subscribes well into contemporary trends in tourism, such as the need for closer contact with nature (Taylor 2009), relaxation in areas of attractive landscapes (Pikkemaat et al., 2009), 
curiosity regarding local products, exploration of cultural heritage, including culinary heritage, and focus on experience (Larsen 2007; Pikkemaat et al., 2009). Thus, wine tourism provides an alternative to mass tourism and may attract visitors to less popular places, contributing thereby to the regional sustainable development. None of the vineyards in Lower Silesia is located in the most visited tourist 'hotspots', as these occur further up in the Sudetes, and only a few are within popular places of one-day weekend recreation (vicinities of Sobótka and Trzebnica). Thus, they may indeed contribute to promotion of less visited parts of the region.

However, continuity and stability of viticulture in Lower Silesia in the current state of sustainable, small-scale cultivation is by no means certain. Due to the lack of local and family traditions of winemaking it is an open question how this industry will develop. One significant uncertainty regards the continuation of wine production by subsequent generations of the current vineyard owners. Their withdrawal from business may result in either abandonment of existing vineyards or intensification of production due to the takeover of smaller vineyards by larger producers, possibly also in increasing cooperation based on raw material supply to larger wineries, as is already the case in the Adoria Vineyard. On the other hand, interviews with vineyard owners revealed that considerable interest in setting up new vineyards exists and potentially suitable land is increasingly being bought for that purpose, especially in the Trzebnica Hills and around Wrocław. If this trend continues, landscape transformation towards true winescapes may locally occur with time, giving new visual dimension to the rural space of Lower Silesia.

Second, market factors may influence the future of vineyards. Increased competition resulting from an increasing number of vineyards can induce trend towards reduction of production costs by moving away from environmentally friendly methods. Finally, ongoing climate change may matter too. Global warming is often seen as beneficial for wine industry, opening new regions to viticulture (Jones, White, Cooper, \& Storchmann, 2005; Schultz \& Jones, 2010), but most climate change scenarios predict increasing instability of weather even if the general trend is towards higher temperatures. Climate change has already affected food security because of warming, changes in precipitation patterns, and greater frequency of some extreme events (IPCC 2019). Extreme natural phenomena such as late frosts, droughts, hail events and thunderstorms are capable of damaging the vineyards and small vineyards, such as those in Lower Silesia, may be particularly vulnerable due to their small size and increasing probability of complete destruction if a high-magnitude atmospheric event occurs. Furthermore, global warming can help to transform winemaking into mass production in the areas, where currently it is still a small-scale, sustainable activity. Literature suggests that intensification of viticulture causes a number of environmental and landscape impacts, as well as social conflicts, and winemaking industry has little in common with a "natural product" or sustainable wine tourism any longer (Lourenço-Gomes, Pinto, \& Rebelo, 2015; Baird, Hall, \& Castka, 2018; Basso, 2019).

\section{Conclusions}

As the outcome of this study, the following conclusions may be offered. The development of wine industry in Lower Silesia is a new element in the local economy, but it refers to the regional traditions of viticulture, which have disappeared in Lower Silesia for various reasons. The impact of vineyards on the rural landscape is limited, mainly due to their small size, both individually and in total. In a few cases only they significantly contribute to the visual quality of the space. Backed up with historical justification, they should be viewed as an enriching rather than disturbing element. In addition, some wineries include revitalized historical buildings, representing thereby successful examples of conservation of local architectural heritage. 
This study revealed the profile of Lower Silesian winemakers. Typically, they have no formal agricultural education and are newcomers for whom winemaking is primarily a passion and currently an additional rather than the main source of income. However, they have considerable knowledge of wine industry, acquired from self-education and through participation in various courses and training activities. Winemakers are aware of the value of local products, traditions and aesthetic aspects of the landscape, to which they often refer both in activities directly related to wine production, as well as in those focused on enotourism.

Vineyards are small family-business enterprises, so they do not contribute directly to employment growth in the area, but due to the multiplier effect in tourism they can increase local revenues. This is because they contribute to the tourist attractiveness of the places where they are located, and also enrich the educational and cultural dimension of the rural space. However, no solid data exist so far to quantify this effect.

Although winemaking industry in Lower Silesia is growing, its future is not yet certain. Several factors may prove detrimental to its further development. Climate warming will foster the establishment of new vineyards, however predicted higher frequency of various climate anomalies (late frosts, heat waves and droughts, severe rainfall, including hail events) may increase risk factor in wine production. Another factor difficult to predict is the willingness (or lack of it) to continue winemaking among next generations of the current vineyard owners. On the other hand, the contemporary modest success of wine industry in the region may attract further people to invest in winemaking.

Despite geographical proximity, winemaking regions in Germany, Moravia or Lower Austria are not good analogues to the developing wine industry in Lower Silesia. This is due to scale and long, largely unbroken traditions of wine industry in those regions since centuries. Rather, one can notice similarities between trends currently observed in Lower Silesia and those experienced in regions which have never had traditions of winemaking or its continuity was interrupted for more than a century. These include southern Canada, England, Denmark and Scania in Sweden.

\section{Editors' note:}

Unless otherwise stated, the sources of tables and figures are the authors', on the basis of their own research.

\section{References}

Alant, K., Bruwer, J. (2004). Wine tourism behaviour in the context of a motivational framework for wine regions and cellar doors. Journal of Wine Research, 15(1), 27-37. https://doi.org/10.1080/0957126042000300308

Alonso, A.D., O'Neill, M.A. (2009). Wine tourism in Spain: The case of three wine regions. Tourism, 57(4), 405-420.

Bardel, M., Gogoliński, W. (2018). Wiedza o winie: Tom II. Geografia wina. Stary Świat. Kraków: Wydawnictwo Czas Wina.

Basso, M. (2019). Land-use changes triggered by the expansion of wine-growing areas: A study on the Municipalities in the Prosecco's production zone (Italy). Land Use Policy, 83, 390-402. https://doi.org/10.1016/j.landusepol.2019.02.004

Baird, T., Hall, C., Castka, P. (2018). New Zealand winegrowers attitudes and behaviours towards wine tourism and sustainable winegrowing. Sustainability, 10(3), 797. https://doi.org/10.3390/su10030797 
Błaszczyk, J., Krzywonos, M. (2015). Analiza właściwości moszczów winnych i win na przykładzie winnicy z Dolnego Śląska. Prace Naukowe Uniwersytetu Ekonomicznego we Wrocławiu, 411, 9-18. https://doi.org/10.15611/pn.2015.411.01

Bosak, W. (2013). Opłacalność produkcji wina oraz możliwości rozwoju komercyjnego winiarstwa w Polsce. Polski Instytut Wina i Winorośli. [14 August 2019] www.winologia.pl/ekonomika

Bruwer, J. (2003). South African wine routes: Some perspectives on the wine tourism industry's structural dimensions and wine tourism product. Tourism Management, 24, 423-435. https://doi.org/10.1016/s0261-5177(02)00105-x

Bruwer, J., Joy, A. (2017). Tourism destination image (TDI) perception of Canadian regional winescape: a free-text macro approach. Tourism Recreational Research, 42(3), 367-379. https://doi.org/10.1080/02508281.2017.1318482

Carmichael, B. (2005). Understanding the wine tourism experience for winery visitors in the Niagara Region, Ontario, Canada. Tourism Geographies, 7(2), 185-204. https://doi.org/10.1080/14616680500072414

Carlsen, J. (2004). A review of global wine tourism research. Journal of Wine Research, 15(1), 5-13. https://doi.org/10.1080/0957126042000300281

Carlsen, J., Charters, S. (Eds). (2006). Global wine tourism: Research, management and marketing. Wallingford: CABI. https://doi.org/10.1079/9781845931704.0000

Charters, S., Ali-Knight, J.(2002). Who is the wine tourist? Tourism Management, 23(3), 311-319. https://doi.org/10.1016/S0261-5177(01)00079-6

Charzyński, P., Podgórski, Z. (2017). Polscy biro- i enoturyści - wstępna charakterystyka komparatystyczna. Turystyka kulturowa, 5, 88-102.

Dawson, H., Holmes, M., Jacobs, H., Wade, R.I. (2011). Wine tourism: Winery visitation in the wine appellations of Ontario. Journal of Vacation Marketing, 17(3), 237-246. https://doi.org/10.1177\%2F1356766711409185

Dobrowolska-Iwanek, J., Gąstol, M., Wanat, A., Krośniak, M., Jancik, M., Zagrodzki, P. (2014). Wine of cool-climate areas in south Poland, South African Journal of Enology and Viticulture, 35(1), 1-9. https://doi.org/10.21548/35-1-980

Dodd, T., Beverland, M. (2001). Winery tourism life-cycle development: A proposed model. Tourism Recreational Research, 26(2), 11-21. https://doi.org/10.1080/02508281.2001.11081339

Dolnośląski Szlak Piwa i Wina (Lower Silesia Trail of Beer and Wine). Retrieved from http://www.dspiw.pl [31 August 2019].

Foronda-Robles, C. (2018). The territorial redefinition of the vineyard landscape in the sherry wine region (Spain). Miscellanea Geographica, 22(2). 95-101. https://doi.org/10.2478/mgrsd-2018-0010

Garibaldi, R., Stone, M.J., Wolf, E., Pozzi, A. (2017). Wine travel in the United States: A profile of wine travellers and wine tours. Tourism Management Perspectives, 23, 53-57. https://doi.org/10.1016/j.tmp.2017.04.004

Getz, D., Brown, G. (2006). Critical success factors for wine tourism regions: A demand analysis. Tourism Management, 27(1), 146-158. https://doi.org/10.1016/j.tourman.2004.08.002

Głabiński, Z., Koźmiński, C. (2019). Turystyka winiarska jako czynnik lokalnego rozwoju obszarów wiejskich województwa zachodniopomorskiego. Folia Turistica, 53, 263-284. https://doi.org/10.5604/01.3001.0013.7520

Greinert, A., Kostecki, J., Vystavna, Y. (2019). The history of viticultural land use as a determinant of contemporary regional development in Western Poland. Land Use Policy, 85, 249-258. https://doi.org/10.1016/j.landusepol.2019.04.010

Hall, C.M., Sharples, L., Cambourne, B., Macionis, N. (2009). Wine tourism around the world. London: Routledge. https://doi.org/10.4324/9780080521145 
Harea, O., Eplenyi, A. (2017). Viticultural landscape patterns - embedding contemporary wineries into landscape site. Scientific Journal of Latvia University of Agriculture. Landscape Architecture and Art, 10(10), 7-14. https://doi.org/10.22616/j.landarchart.2017.10.01

Howley, M., van Westering, J. (2008). Developing wine tourism. A case study of the attitude of English wine producers to wine tourism. Journal of Vacation Marketing, 14(1), 87-95. https://doi.org/10.1177\%2F1356766707084221

IPCC. (2019). IPCC Special Report on Climate Change, Desertification, Land Degradation, Sustainable Land Management, Food Security, and Greenhouse gas fluxes in Terrestrial Ecosystems. [31 August 2019] https://www.ipcc.ch/report/srccl/

Jones, G.V., White, M.A., Cooper, O.R., Storchmann, K. (2005). Climate change and global wine quality. Climatic change, 73(3), 319-343. https://doi.org/10.1007/s10584-005-4704-2

Karvonen, J. (2017). Impact of climate change on winegrowing condition in southernmost Finland (Tuusula). International Journal of Enology and Viticulture, 4,169-178.

Kosmaczewska, J. (2008). Szlaki wina w Polsce - perspektywy i bariery rozwoju. Studia Periegetica, 2, 153-160.

Kowalczyk, A. (2003). Szlaki wina - nowa forma aktywizacji turystycznej obszarów wiejskich. Prace i Studia Geograficzne, 32, 69-98.

Kowalczyk, A. (2010). Turystyka zrównoważona. Warszawa: PWN.

Krajowy Ośrodek Wsparcia Rolnictwa (the National Support Centre for Agriculture). Retrieved from http://www.kowr.gov.pl [31 August 2019].

Królikowska, K., Pijet-Migoń, E. (2018). Możliwości rozwoju turystyki winiarskiej na Dolnym Śląsku, Rozprawy Naukowe AWF we Wrocławiu, 63, 114-128.

Kruczek, Z. (2018). Małopolski szlak winny - droga od przemysłu do produktu turystycznego, Zeszyty Naukowe Uczelni Vistula, 60(3) 130-142.

Kundzewicz, Z.W. (2011). Zmiany klimatu, ich przyczyny i skutki - obserwacje i projekcje. Landform Analysis, 15, 39-49.

Kunicka-Styczyńska, A., Czyżowska, A., Ratajkowska, K., Witkowska, A., Dziugan, P. (2016). The trends and prospects of winemaking in Poland. In A. Morata (ed.), Grape and Wine Biotechnology (pp. 401-413). https://doi.org/10.5772/64976

Larsen, S. (2007). Aspects of psychology of the tourist experience. Scandinavian Journal of Hospitality and Tourism, 7(1), 7-18. https://doi.org/10.1080/15022250701226014

Lieskovský, J., Kanka, R., Bezák, P., Štefunková, D., Petrovič, F., Dobrovodská, M. (2013). Driving forces behind vineyard abandonment in Slovakia following the move to a market-oriented economy. Land Use Policy, 32, 356-365. https://doi.org/10.1016/j.landusepol.2012.11.010

Lisek, J. (2008). Climatic factors affecting development and yielding of grapevine in Central Poland. Journal of Fruit and Ornamental Plant Research, 16, 285-293

Lourenço-Gomes, L., Pinto, L.M., Rebelo, J. (2015). Wine and cultural heritage. The experience of the Alto Douro Wine Region. Wine Economics and Policy, 4(2) 78-87. https://doi.org/10.1016/j.wep.2015.09.001

López-Guzmán, T., Vieira-Rodríguez, A., Rodríguez-García, J. (2014). Profile and motivations of European tourists on the Sherry wine route of Spain. Tourism Management Perspectives, 11, 63-68. https://doi.org/10.1016/j.tmp.2014.04.003

Lugeri, F.R., Amadio, V., Bagnaia, R., Cardilo, A., Lugeri, N. (2011). Landscape and wine production areas: a geomorphological heritage. Geoheritage, 3(3), 221-232. https://doi.org/10.1007/s12371-011-0035-z

Matkowski, J., Miętkiewicz-Brynda, J. (2015). Turystyka winiarska w Polsce. Zeszyty Naukowe. Turystyka i Rekreacja. Wyższa Szkoła Turystyki i Języków Obcych w Warszawie, 1(15), 163-173.

Mazurkiewicz-Pizło, A. (2012). Turystyka winiarska (enoturystyka) - korzyści i koszty. Zeszyty Naukowe Uniwersytetu Szczecińskiego. Ekonomiczne Problemy Turystyki, 84(699), 633-645. 
Mazurkiewicz-Pizło, A. (2013). Enoturystyka jako szansa rozwoju społeczno-ekonomicznego obszarów wiejskich. Warszawa-Toruń: Dom Organizatora.

Mazurkiewicz-Pizło, A. (2014). The importance of non-profit organisations in developing wine tourism in Poland. Journal of Tourism and Cultural Change, 14(4), 339-349. https://doi.org/10.1080/14766825.2015.1102922

Mazurkiewicz-Pizło, A., Pizło, W. (2018). Determinants of the development of vineyards and wine tourism in Poland, Acta Scientiarum Polonorum Oeconomia, 17(4), 115-121. https://doi.org/10.22630/aspe.2018.17.4.58

Ministry of Agriculture and Rural Development (Ministerstwo Rolnictwa i Rozwoju Wsi), Traditional Product List (Lista Produktów Tradycyjnych. Wino śląskie). Retrieved from http://www.minrol.gov.pl [19 August 2019].

Myga-Piątek, U., Rahmonov, O. (2018). Winery regions as the oldest cultural landscapes: remnants, signs, and metamorphoses. Miscellanea Geographica, 22(2), 69-80. https://doi.org/10.2478/mgrsd-2018-0009

Myśliwiec, R. (2013). Uprawa winorośli. Warszawa: Państwowe Wydawnictwo Rolnicze i Leśne.

National Support Centre for Agriculture (Krajowy Ośrodek Wsparcia Rolnictwa). Retrieved from http://www.kowr.gov.pl [14 August 2019].

Nesbitt, A., Kemp, B., Steele, C., Lovett, A., Dorling, S. (2016). Impact of recent climate change and weather variability on the viability of UK viticulture - combining weather and climate records with producers' perspectives. Australian Journal of Grape and Wine Research, 22(2), 324-335. https://doi.org/10.1111/ajgw.12215

Olszewski, J., Dróżdż, R. (2013). Polska oferta w zakresie enoturystyki. Hygeia Public Health, 48(4), 436-440.

Olewnicki, D. (2018). Uprawa winorośli w Polsce w świetle danych statystycznych. Roczniki Naukowe Stowarzyszenia Ekonomistów Rolnictwa i Agrobiznesu, 20(5), 139-145.

Pikkemaat, B., Peters, M., Boksberger, P., Secco, M. (2009). The staging of experiences in wine. Journal of Hospitality Marketing and Management, 18, 237-253. https://doi.org/10.1080/19368620802594110

Piatyszek-Pych, A. (2012). The state and the development prospects of the Lubusz cluster initiative "The Lubusz Wine and Honey Route". Management, 16(2), 155-174. https://doi.org/10.2478/v10286-012-0063-z

Pijet-Migoń, E., Migoń, P. (2019). Promoting and interpreting geoheritage at the local level-bottom-up approach in the Land of Extinct Volcanoes, Sudetes, SW Poland. Geoheritage, 11, 1227-1236. https://doi.org/10.1007/s12371-019-00357-2

Pink, M. (2015). Polska jako kraj winiarski? Od tradycji do rodzących się możliwości. Problemy Drobnych Gospodarstw Rolnych, 2, 37-56. https://doi.org/10.15576/pdgr/2015.2.37

Pink, M., Kokoszka, K. (2018). Winiarstwo i winogrodnictwo miejskie - funkcje i potencjał zjawiska, Problemy Drobnych Gospodarstw Rolnych, 3, 65-77. https://doi.org/10.15576/pdgr/2018.3.65

Poczta, J., Zagrocka, M. (2016). Uwarunkowania rozwoju turystyki winiarskiej w Polsce na przykładzie regionu zielonogórskiego. Turystyka Kulturowa, 5, 115-130.

Rogowski, M., Kasianchuk, A. (2016). Atrakcyjność turystyczna winnic Lubuskiego Szlaku Wina i Miodu. Zeszyty Naukowe. Turystyka i Rekreacja, 2, 101-118. https://doi.org/10.5604/01.3001.0010.6943

Rzeszotarska-Pałka, M. (2012). Tradycja winnych sadów na terenie Pomorza Zachodniego. Czasopismo Techniczne. Architektura, 109(8-A), 145-152.

Sadura, P., Murawska, K., Włodarczyk, Z. (2017). Wieś w Polsce 2017: diagnoza i prognoza, Warszawa: Fundacja Wspomagania Wsi. 
Schernewski, G. (2011). Adaptation to climate change: Viniculture and tourism at the Baltic coast. In G. Schernewski, J. Hofstede, T. Neumann (eds.), Global change and Baltic coastal zones (pp. 249-273). Dordrecht: Springer.

Schultz, H.R., Jones, G.V. (2010). Climate induced historic and future changes in viticulture. Journal of Wine Research, 21(2-3), 137-145. https://doi.org/10.1080/09571264.2010.530098

Shor, N., Mansfeld, Y. (2009). Between wine consumption and wine tourism: Consumer and spatial behavior of Israeli wine tourists. Tourism, 57(4), 381-403.

Solon, J., Borzyszkowski, J., Bidłasik, M., Richling, A., Badora, K., Balon, J., Brzezińska-Wójcik, T., Chabudziński, Ł., Dobrowolski, R., Grzegorczyk, I., Jodłowski, M., Kistowski, M., Kot, R., Krąż, P., Lechnio, J., Macias, A., Majchrowska, A., Malinowska, E., Migoń, P., Myga-Piątek, U., Nita, J., Papińska, E., Rodzik, J., Strzyż, M., Terpiłowski, S., Ziaja, W.(2018). Physico-geographical mesoregions of Poland: Verification and adjustment of boundaries on the basis of contemporary spatial data. Geographia Polonica, 91(2), 143-170. https://doi.org/10.7163/gpol.0115

Taylor, J.P. (2009). Authenticity and sincerity in tourism. Annals of Tourism Research, 28(1), 7-26. https://doi.org/10.1016/s0160-7383(00)00004-9

Telfer, D.J. (2001). Strategic alliances along the Niagara Wine Route. Tourism Management, 22(1), 21-30. https://doi.org/10.1016/s0261-5177(00)00033-9

Torquati, B., Giacchè, G., Venanzi, S. (2015). Economic analysis of the traditional cultural vineyard landscapes in Italy. Journal of Rural Studies, 39, 122-132.

Wawro, E. (2015). Winnice w Polsce. Warszawa: Oficyna Wydawnicza Multico.

Winnice w Polsce. Retrieved from http://www.winogrodnicy.pl [14 August 2019].

Woźniczko, M.A., Jędrysiak, T., Orłowski, D. (2015). Turystyka kulinarna. Warszawa: PWE.

Żmudzka, E. (2009). Współczesne zmiany klimatu Polski. Acta Agrophysica, 13(2), 555-568.

(C) Edyta Pijet-Migoń • Karolina Królikowska
Article first received • October 2019

Article accepted • July 2020

Open acces article under the CC BY 4.0 license 